\title{
Peritoneal dialysis-associated infection caused by Mycobacterium abscessus: a case report
}

\author{
Ryuichi Yoshimura ${ }^{1}$, Miharu Kawanishi ${ }^{1}$, Shungo Fujii ${ }^{1}$, Aska Yamauchi ${ }^{1}$, Kentaro Takase ${ }^{1}$, Kaori Yoshikane ${ }^{1}$, \\ Masahiro Egawa ${ }^{1}$, Hiroaki Shiina ${ }^{2}$ and Takafumi Ito ${ }^{1 *}$
}

\begin{abstract}
Background: Peritoneal dialysis (PD)-associated infection caused by Mycobacterium spp. is rare. Mycobacterium abscessus is one of the most resistant acid-fast bacteria, and treatment is also the most difficult and refractory. Thus, we report a case of PD-associated peritonitis caused by Mycobacterium abscessus that was difficult to treat and led to PD failure.

Case presentation: We recently encountered a 56-year-old man who developed PD-associated infection. We initially suspected exit-site infection (ESI) and tunnel infection (TI) caused by methicillin-resistant coagulase-negative Staphylococcus. However, antibiotic therapy did not provide any significant improvement. Thus, we performed simultaneous removal and reinsertion of a PD catheter at a new exit site. The patient subsequently developed peritonitis and Mycobacterium abscessus was detected in the peritoneal effluent. Thus, the reinserted catheter was removed, hemodialysis was started, and the patient was eventually discharged.

Conclusions: In cases of refractory ESI or TI, it is important to consider non-tuberculous mycobacteria as the potentially causative organism. Even if acid-fast bacterial staining is negative or not performed, detection of Gramnegative bacillus may lead to suspicion and early identification of Mycobacterium spp. In PD-associated infection by Mycobacterium abscessus, catheter removal is necessary in many cases. Simultaneous removal and reinsertion of the catheter is not recommended, even in cases of ESI or TI. Reinsertion should only be attempted after complete resolution of peritoneal symptoms. After removal of the catheter, careful follow-up is necessary, paying attention to complications such as wound infection, peritonitis, and ileus. In addition, the selection and treatment period of antibiotics in PD-associated infection by Mycobacterium abscessus remains unclear, and it is an important topic for future discussion.
\end{abstract}

Keywords: Peritoneal dialysis, Infection, Mycobacterium abscessus, Peritonitis

\section{Background}

Peritoneal dialysis (PD) is associated with various infectious complications, such as exit-site infection (ESI), tunnel infection (TI), and peritonitis. Various organisms can cause ESI and TI, such as Staphylococcus aureus and Pseudomonas aeruginosa, which can frequently lead to peritonitis. Thus, these infections must be treated aggressively $[1,2]$.

\footnotetext{
* Correspondence: tito@med.shimane-u.ac.jp

${ }^{1}$ Division of Nephrology, Shimane University Hospital, 89-1, Enya-cho, Izumo, Shimane 693-8501, Japan

Full list of author information is available at the end of the article
}

Reports of peritonitis caused by non-tuberculous mycobacteria (NTM) are relatively rare, but are becoming more common [3]. More than $50 \%$ of the isolates are rapidly growing species, such as Mycobacterium fortuitum and $M$. chelonae [4], which are often detected after 3-5 days during routine bacteriological cultures. There is no wellestablished treatment for NTM-related peritonitis, and personalized treatment should be guided by susceptibility testing [5]. Catheter removal is usually necessary, and experience with non-removal is limited [4, 6, 7]. Unfortunately, most cases develop refractory peritonitis, despite long-term treatment, which ultimately causes PD failure.

(c) The Author(s). 2018 Open Access This article is distributed under the terms of the Creative Commons Attribution 4.0 International License (http://creativecommons.org/licenses/by/4.0/), which permits unrestricted use, distribution, and 
Thus, we report a case of PD-associated peritonitis caused by $M$. abscessus that was difficult to treat and led to PD failure.

\section{Case presentation}

A 56-year-old Japanese man with end-stage renal disease secondary to diabetic nephropathy visited our hospital because of abdominal pain and pus discharge from the exit site of a PD catheter. He had redness around the exit site and tenderness at the subcutaneous tunnel. The dialysis effluent was not cloudy and the effluent cell count was $<100 / \mu \mathrm{L}$. Thus, we performed pus swab culture based on a suspicion of ESI and TI. Treatment was started using intravenous vancomycin ( $1.5 \mathrm{~g} /$ day), oral minocycline ( $200 \mathrm{mg} /$ day), and topical gentamicin ointment, because the patient had a history of ESI caused by methicillin-resistant coagulase-negative Staphylococcus (MRCNS).

The patient was admitted to our hospital 3 days later, with the following vital signs: blood pressure of $165 / 104$ $\mathrm{mmHg}$, pulse of $86 \mathrm{bpm}$, and temperature of $36.7^{\circ} \mathrm{C}$. A physical examination revealed continued pus discharge from the exit site, as well as redness and swelling of the surrounding skin (Fig. 1). No rebound tenderness or muscle guarding were observed. A complete blood count from the admission revealed a white blood cell count of $8390 / \mu \mathrm{L}$, a red blood cell count of $380 \times 10^{4} / \mu \mathrm{L}$, a hemoglobin level of $10.1 \mathrm{~g} / \mathrm{dL}$, and a platelet count of $21.4 \times 10^{4} / \mu \mathrm{L}$. The blood test results revealed an albumin level of $2.9 \mathrm{~g} / \mathrm{dL}$, a blood urea nitrogen level of 54.3 $\mathrm{mg} / \mathrm{dL}$, a creatinine level of $13.95 \mathrm{mg} / \mathrm{dL}$, and a C-reactive protein (CRP) level of $0.09 \mathrm{mg} / \mathrm{dL}$. The white cell count in the dialysis effluent was $7 / \mu \mathrm{L}$ (mononuclear cells: $6 / \mu \mathrm{L}$, polymorphonuclear cells: $1 / \mu \mathrm{L}$ ), and the pus culture revealed the presence of MRCNS.

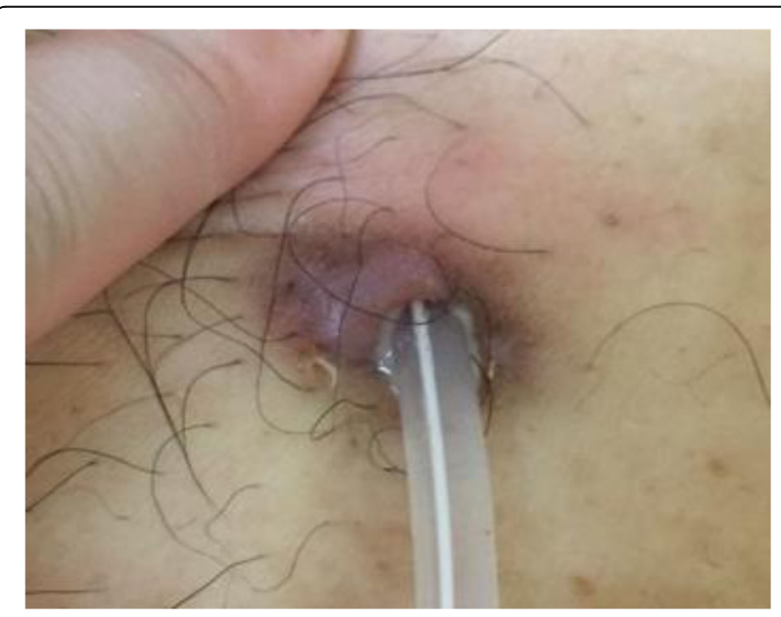

Fig. 1 The catheter exit site on the day of admission. Redness and swelling are clearly visible around the catheter exit site
We continued to suspect that the ESI and TI were caused by MRCNS, and continued treatment using intravenous vancomycin (Fig. 2). However, abdominal computed tomography on day 7 revealed an increased density of fatty tissue around the PD catheter (Fig. 3 a, b). Thus, we performed simultaneous removal and reinsertion of the PD catheter at a new exit site, based on the refractory ESI and TI in the absence of peritonitis. The PD was re-started on day 12 , although evaluation of the dialysis effluent on day 15 revealed that the white cell count had increased to $631 / \mu \mathrm{L}$ (mononuclear cells: $455 / \mu \mathrm{L}$, po lymorphonuclear cells: $176 / \mu \mathrm{L}$ ), which supported a diagnosis of peritonitis. Negative results were obtained from Gram staining and acid-fast staining of the dialysis effluent. The dialysis effluent was then cultured in aerobic, anaerobic, and Ogawa media. Treatment was switched to intravenous meropenem $(0.5 \mathrm{~g} /$ day $)$ and intraperitoneal amikacin $(2 \mathrm{mg} / \mathrm{kg} /$ day $)$. On day 23 , we observed a rise in the CRP level $(10.1 \mathrm{mg} / \mathrm{dL})$ and the number of white cells in the dialysis effluent $(4126 / \mu \mathrm{L})$. Therefore, the patient was converted to hemodialysis (HD) on day 24 .

On day 29, gram-positive rods (GPR) were found in the aerobic culture of the dialysis effluent from day 15 . These bacilli were sensitive to imipenem but resistant to meropenem and amikacin. On day 30, we noticed growth of acid-fast bacilli in Ogawa medium. The GPR from the aerobic culture were identified as $M$. abscessus on day 33. M. abscessus was also detected in cultures of the dialysis effluents from days 20 and 28. After switching the treatment from meropenem to imipenem, the CRP levels decreased. However, ESI and TI persisted at the reinserted catheter and wound dehiscence was detected at the old exit site (Fig. $3 \mathrm{c}, \mathrm{d}$ ). Thus, the second catheter was removed on day 37 , and the patient's condition subsequently improved. Additional susceptibility testing revealed that the $M$. abscessus was sensitive to clarithromycin, and oral clarithromycin was started after 4 weeks of treatment using imipenem. Cultures of the catheter tip and intraoperative ascites fluid revealed positive results for $M$. abscessus. In addition, pathological findings at the original exit site revealed granulomatous dermatitis and a positive result during acid-fast staining. M. abscessus was detected in the wound cultures until day 58 , although negative results were observed thereafter. On day 101, the patient developed nausea and vomiting, and computed tomography revealed intestinal dilation (Fig. 3 e, f). On day 103, the patient underwent laparoscopic adhesiolysis surgery because of adhesive ileus, and the intraoperative findings revealed adhesion of the intestinal tract near the abdominal wall site where the catheter had been placed. There were no findings of encapsulating peritoneal sclerosis, and $M$. abscessus was not detected during culture of the intraoperative ascites specimen. The patient was 


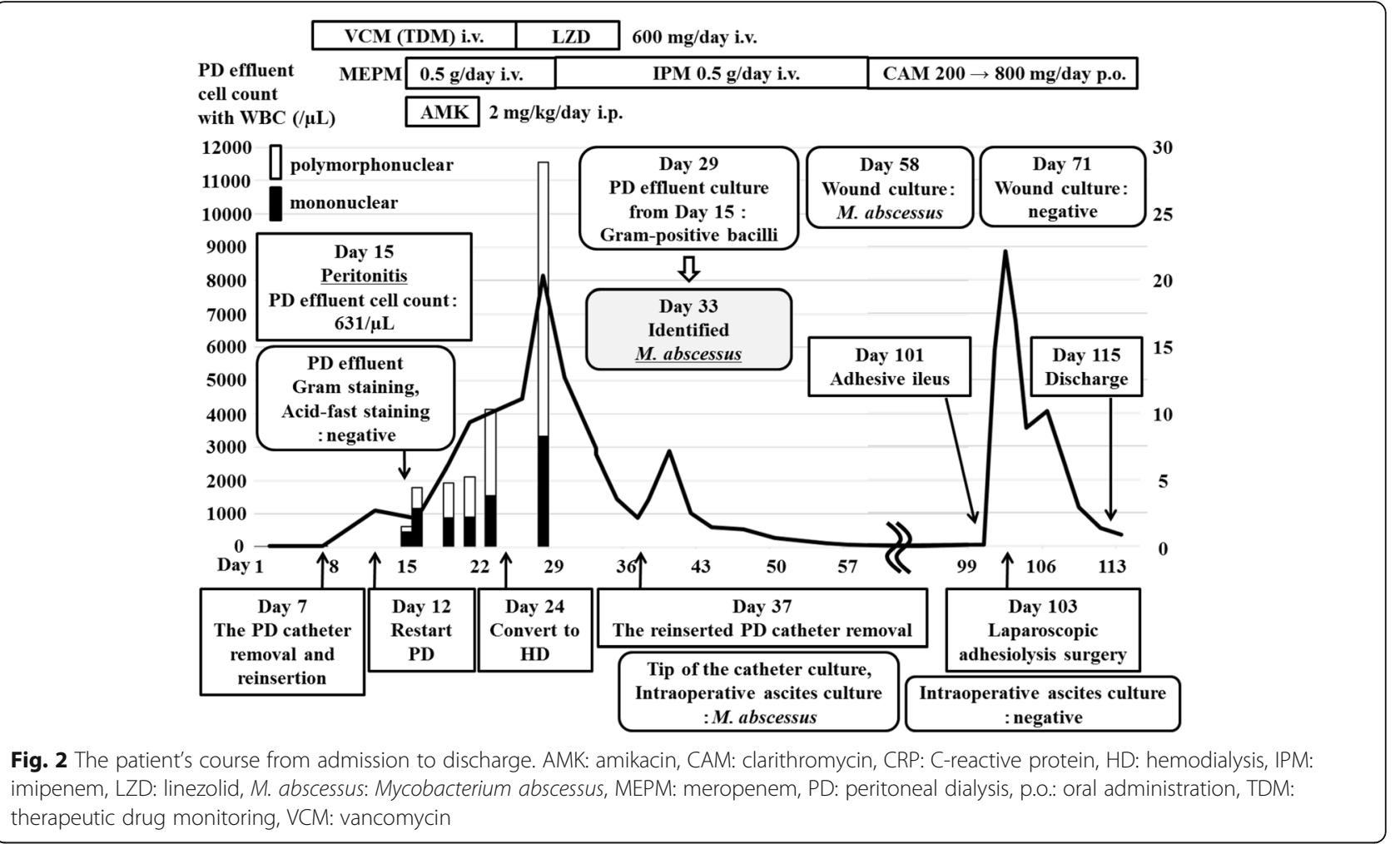

discharged on day 115, completed 6 months of treatment using clarithromycin monotherapy, and did not develop infection or ileus recurrence during the next 2 years.

\section{Discussion and conclusions}

$M$. abscessus belongs to the Ruyon classification group IV of rapidly-growing mycobacteria (RGNTM), which often provide positive results on routine bacteriologic cultures within 7 days. Although M. abscessus was previously classified as an $M$. chelonae subspecies, it was reclassified as an individual species in 1992 [8]. This organism is ubiquitous in soil and water, and commonly causes skin, soft tissue, bone, and respiratory infections.

Renaud et al. reported that RGNTM infections accounted for $3 \%$ of all culture-positive ESI and PD peritonitis cases [6]. Thus, RGNTM are a rare cause of PD-associated infections. Furthermore, among 57 cases of PD-associated NTM peritonitis, the most prevalent organism was M. fortinum (38.6\%), which was followed by $M$. chelonae (14.0\%), M. avium complex (10.5\%), and M. abscessus (8.8\%) [4]. Between 1998 and 2017, there have been 28 reported cases of PD-associated infection

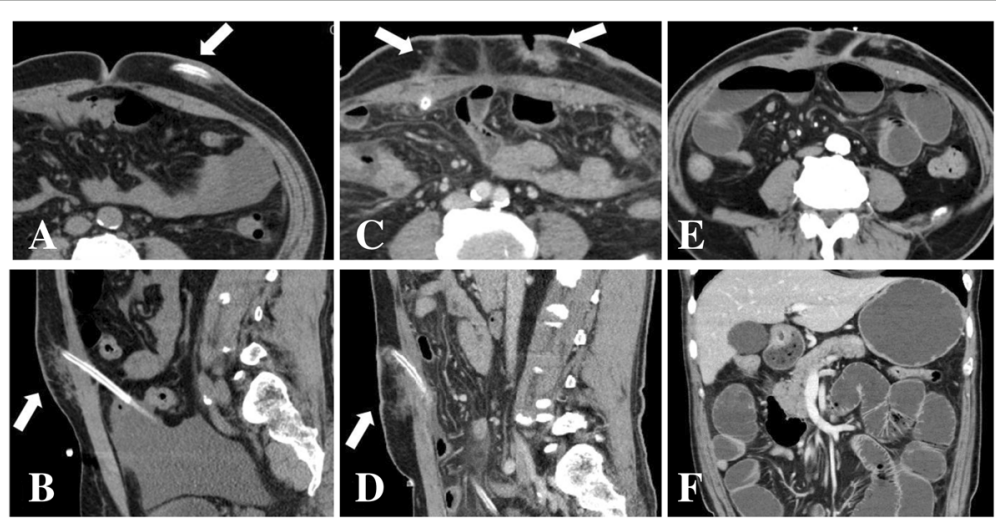

Fig. 3 Radiological findings. On day 7, abdominal computed tomography revealed an increased density of fatty tissue around the PD catheter (arrows in $\mathbf{a}, \mathbf{b}$ ). On day 30, wound dehiscence was observed at the original exit site, with increased density of fatty tissue around the new catheter (arrows in $\mathbf{c}, \mathbf{d}$ ). On day 101, intestinal dilation was observed $(\mathbf{e}, \mathbf{f})$ 
caused by $M$. abscessus [6, 7, 9-18], and their characteristics are summarized in Table 1 . The reported cases included 16 males and 12 females with a median age of 59 years (range: 14-89). Twenty-one cases (75.0\%) involved ESI or TI at the beginning of treatment, which were thought to be para-catheter infections. However, 7 cases (25.0\%) involved peritonitis without ESI or TI, which were thought to be transcatheter infections. The large proportion of para-catheter infections may be because mycobacteria are susceptible to heat and ultraviolet light, but can be resistant to disinfectants because they have large amounts of lipids in the cell wall, which can render benzalkonium chloride and chlorhexidine gluconate ineffective. The International Society for Peritoneal Dialysis (ISPD) guidelines recommend daily application of antibiotic cream or ointment to the catheter exit site, because it could prevent ESI caused by Staphylococcus aureus and Pseudomonas species [5]. However, extensive use of gentamicin ointment for ESIs may predispose patients to NTM infections of the exit site [13, 19]. In the present case, the patient had worked in a forest several times, and had used benzalkonium chloride to clean the exit site, which may have increased the risk of NTM infection.

An official American Thoracic Society/Infectious Diseases Society of America (ATS/IDSA) statement has recommended that surgery is generally indicated for cases of $M$. abscessus infection with extensive disease, abscess formation, or where antibiotic therapy is difficult. Thus, removal of foreign bodies (e.g., percutaneous catheters) is important and probably essential to recovery [20]. Among the 28 reported cases, 24 cases (85.7\%) involved catheter removal during treatment, and only 4 cases (14.5\%) did not involve catheter removal. Moreover, only 2 patients $(7.1 \%)$ continued PD during antibiotic treatment or debridement without removing the catheter, and both cases involved ESI or TI without peritonitis. Two other patients died, with 1 patient dying 16 months after developing peritonitis [13], and the other selecting palliative care after developing enterococcal and candidal peritonitis [6]. Among the 24 cases with catheter removal, 23 cases were converted to HD and 1 case was shifted to palliative care. Three cases with ESI or TI but no peritonitis underwent simultaneous removal and reinsertion of the catheter, although all cases were refractory, required subsequent catheter removal, and were ultimately converted to HD. Six other cases received a second catheter after resolution of the peritoneal symptoms and were converted back to $\mathrm{PD}$, with a reinsertion interval of 4 weeks to 9 months. Among the 23 cases with catheter removal and conversion to HD, 1 patient died after 8 months because of renal hemorrhage and retroperitoneal infection, and a second patient died after 5 months because of peritoneal sclerosis $[7,11]$.
In the studies mentioned above, all patients with peritonitis had their catheters removed. Only two cases of ESI or TI continued PD without progressing to peritonitis, without the removal of the catheter. Hence, there is a possibility to continue PD without catheter removal if M. abscessus is identified early and before progressing to peritonitis, provided appropriate antibiotic therapy has started. In this context, acid-fast staining should have been performed to rapidly detect Mycobacterium spp., although Song et al. reported that $33.3 \%$ of cases involved smear-negative disease [4]. Therefore, in many cases there might be a prolonged delay to identify $M$. abscessus, and the ESI or TI can progress to refractory peritonitis. In our case, MRCNS was detected in the swab culture at the initial visit, but it was thought to be a skin indigenous bacterium from the course. Acid-fast staining of the dialysis effluent was negative at the time of peritonitis diagnosis, but gram-positive bacilli were detected on repeated cultures, and M. abscessus was identified. In addition to our case, at least 3 of the 28 reported cases of PD-associated infection caused by $M$. abscessus were initially positive for Gram-positive bacilli, and were diagnosed as $M$. abscessus at a later date. Therefore, we believe that the detection of gram-positive bacillus should alert the clinician to the possible presence of Mycobacterium spp., and lead to early identification regardless of acid-fast staining results. In the ISPD guidelines, there is no algorithm to follow if gram-positive bacilli are present, but it is considered to be an important finding in the differentiation of $\mathrm{Myco}$ bacterium spp.

Many cases may require a prolonged interval to identify $M$. abscessus, and the ESI or TI can progress to refractory peritonitis. Simultaneous reinsertion of a new PD catheter may prolong ESI or TI caused by M. abscessus, even in the absence of peritonitis. Thus, catheter reinsertion should only be attempted after the original catheter has been removed and the peritoneal symptoms have completely resolved.

Antibiotic susceptibility testing is recommended in similar cases, as $M$. abscessus has variable susceptibility, although it is uniformly resistant to the standard antituberculous agents [21-23]. According to the ATS/IDSA, serious skin, soft tissue, and bone infections caused by M. abscessus should be treated using clarithromycin or azithromycin plus parenteral medication, such as amikacin, cefoxitin, or imipenem [20]. The macrolides are the only oral agents that are reliably active against $M$. abscessus in vitro [22, 24], and the most active parenteral agent is amikacin. However, acquired mutational resistance to clarithromycin and amikacin can occur, because M. abscessus only has a single copy of the related gene. The isolate in the present case was sensitive to clarithromycin and imipenem, but was resistant to amikacin. 
Table 1 Comparison of the present case with previously reported PD-associated infections caused by Mycobacterium abscessus

\begin{tabular}{|c|c|c|c|c|c|c|c|}
\hline Reference & Year & $\begin{array}{l}\text { Duration } \\
\text { of PD }\end{array}$ & $\begin{array}{l}\text { Cause of ESRD, } \\
\text { Underlying disease }\end{array}$ & $\begin{array}{l}\text { Infection } \\
\text { type at } \\
\text { initial treatment }\end{array}$ & $\begin{array}{l}\text { Surgical } \\
\text { intervention }\end{array}$ & Clinical outcome & Antibiotics (duration) \\
\hline $\begin{array}{l}\text { The } \\
\text { present } \\
\text { case }\end{array}$ & 2017 & $\begin{array}{l}3 \\
\text { months }\end{array}$ & DMN & $\mathrm{ESI}, \mathrm{TI}$ & $\begin{array}{l}\text { Simultaneous } \\
\text { catheter removal } \\
\text { and reinsertion }\end{array}$ & $\begin{array}{l}\text { Removed the reinserted catheter } \\
\text { because of developing } \\
\text { peritonitis, and converted to HD }\end{array}$ & $\begin{array}{l}\text { CAM ( } 6 \text { months), IPM ( } 4 \\
\text { weeks) }\end{array}$ \\
\hline 9 & 2017 & $\begin{array}{l}12 \\
\text { months }\end{array}$ & nephrolithiasis & ESI & $\begin{array}{l}\text { Simultaneous } \\
\text { catheter removal } \\
\text { and reinsertion }\end{array}$ & $\begin{array}{l}\text { Removed the reinserted catheter } \\
\text { because of prolonged ESI, and } \\
\text { converted to HD }\end{array}$ & CAM, IPM, TGC (N/A) \\
\hline 10 & 2017 & $\begin{array}{l}6 \\
\text { months }\end{array}$ & DMN & ESI & $\begin{array}{l}\text { Catheter } \\
\text { removal }\end{array}$ & Paliative care & $\begin{array}{l}\text { CAM ( } 44 \text { days), AMK ( } 25 \\
\text { days), IPM ( } 25 \text { days), } \\
\text { FRPM ( } 19 \text { days) }\end{array}$ \\
\hline 11 & 2015 & $\begin{array}{l}96 \\
\text { months }\end{array}$ & N/A & ESI, peritonitis & $\begin{array}{l}\text { Catheter } \\
\text { removal }\end{array}$ & $\begin{array}{l}\text { Converted to HD, and died after } \\
8 \text { months because of renal } \\
\text { hemorrhage and retroperitoneal } \\
\text { infection }\end{array}$ & $\begin{array}{l}\text { CAM (165 days), AMK ( } 68 \\
\text { days), MEPM ( } 165 \text { days), } \\
\text { LVFX ( } 111 \text { days) }\end{array}$ \\
\hline 11 & 2015 & $\begin{array}{l}70 \\
\text { months }\end{array}$ & DMN & $\mathrm{TI}$, peritonitis & $\begin{array}{l}\text { Catheter } \\
\text { removal }\end{array}$ & Converted to HD & $\begin{array}{l}\text { CAM ( } 234 \text { days), AMK ( } 50 \\
\text { days), IPM ( } 70 \text { days), } \\
\text { CPFX ( } 217 \text { days), DOXY } \\
\text { (180 days) }\end{array}$ \\
\hline 12 & 2013 & $\begin{array}{l}12 \\
\text { months }\end{array}$ & Herb related & $\mathrm{ESI}, \mathrm{TI}$ & $\begin{array}{l}\text { Debridement } \\
\text { Continued PD } \\
\text { without catheter } \\
\text { removal }\end{array}$ & Continued PD & $\begin{array}{l}\text { CAM ( } 2 \text { months), CPFX ( } 2 \\
\text { months), RFP ( } 2 \text { months) }\end{array}$ \\
\hline 7 & 2013 & N/A & N/A & peritonitis & $\begin{array}{l}\text { Catheter } \\
\text { removal }\end{array}$ & $\begin{array}{l}\text { Converted to HD, and died after } \\
5 \text { months because of peritoneal } \\
\text { sclerosis }\end{array}$ & CEZ, GM (N/A) \\
\hline 7 & 2013 & N/A & N/A & peritonitis & $\begin{array}{l}\text { Catheter } \\
\text { removal }\end{array}$ & Converted to HD & $\begin{array}{l}\text { AMK, CFX, VCM, GM, } \\
\text { MFIPC (N/A) }\end{array}$ \\
\hline 7 & 2013 & N/A & $\mathrm{N} / \mathrm{A}$ & peritonitis & $\begin{array}{l}\text { Catheter } \\
\text { removal }\end{array}$ & Converted to HD & $\begin{array}{l}\text { CAM, TIPC/CVA, VCM, } \\
\text { GM (N/A) }\end{array}$ \\
\hline 13 & 2012 & $\begin{array}{l}13 \\
\text { months }\end{array}$ & IgAN, DM, HTN & ESI & $\begin{array}{l}\text { Catheter } \\
\text { removal }\end{array}$ & $\begin{array}{l}\text { Converted to } \mathrm{HD} \text {, and reinserted } \\
\text { a new PD catheter after } 5 \\
\text { months }\end{array}$ & $\begin{array}{l}\text { CAM ( } 28 \text { weeks), AMK ( } 8 \\
\text { weeks), LVFX ( } 4 \text { weeks), } \\
\text { MEPM ( } 2 \text { weeks) }\end{array}$ \\
\hline 13 & 2012 & $\begin{array}{l}>60 \\
\text { months }\end{array}$ & $\begin{array}{l}\text { crescentic } \\
\text { mesangioproliferative } \\
\text { gromerulonephritis }\end{array}$ & ESI, peritonitis & $\begin{array}{l}\text { Catheter } \\
\text { removal }\end{array}$ & Converted to HD & $\begin{array}{l}\text { AMK (8 weeks), CFX ( } 28 \\
\text { weeks), MEPM ( } 4 \text { weeks) }\end{array}$ \\
\hline 13 & 2012 & $\begin{array}{l}49 \\
\text { months }\end{array}$ & DMN & ESI, & $\begin{array}{l}\text { Continued PD } \\
\text { without catheter } \\
\text { removal }\end{array}$ & $\begin{array}{l}\text { Died after } 16 \text { months because of } \\
\text { peritonitis }\end{array}$ & $\begin{array}{l}\text { CAM (14 weeks), AMK } \\
\text { (14 weeks), }\end{array}$ \\
\hline 13 & 2012 & $\begin{array}{l}19 \\
\text { months }\end{array}$ & MPA & ESI & $\begin{array}{l}\text { Continued PD } \\
\text { without catheter } \\
\text { removal }\end{array}$ & Continued PD & $\begin{array}{l}\text { CAM ( } 42 \text { weeks), AMK ( } 8 \\
\text { weeks) }\end{array}$ \\
\hline 13 & 2012 & $\begin{array}{l}3 \\
\text { months }\end{array}$ & obstructive uropathy & peritonitis & $\begin{array}{l}\text { Catheter } \\
\text { removal }\end{array}$ & $\begin{array}{l}\text { Converted to } \mathrm{HD} \text {, and reinserted } \\
\text { a new PD catheter after } 9 \\
\text { months }\end{array}$ & $\begin{array}{l}\text { AMK ( } 4 \text { weeks), AZM (6 } \\
\text { weeks), MFLX ( } 20 \text { weeks) }\end{array}$ \\
\hline 13 & 2012 & $\begin{array}{l}>20 \\
\text { months }\end{array}$ & DMN & $\mathrm{ESI}, \mathrm{TI}$ & $\begin{array}{l}\text { Catheter } \\
\text { removal }\end{array}$ & Converted to HD & $\begin{array}{l}\text { CAM ( } 11 \text { weeks), MEPM } \\
(5 \text { weeks })\end{array}$ \\
\hline 14 & 2012 & $\mathrm{~N} / \mathrm{A}$ & CGN & $\mathrm{ESI}, \mathrm{TI}$ & $\begin{array}{l}\text { Catheter } \\
\text { removal }\end{array}$ & $\begin{array}{l}\text { Converted to } \mathrm{HD} \text {, and reinserted } \\
\text { a new PD catheter after } 4 \text { weeks }\end{array}$ & $\begin{array}{l}\text { CAM (14 weeks), IPM (5 } \\
\text { weeks), DOXY (9 weeks) }\end{array}$ \\
\hline 15 & 2012 & $\begin{array}{l}60 \\
\text { months }\end{array}$ & N/A & ESI, peritonitis & $\begin{array}{l}\text { Catheter } \\
\text { removal }\end{array}$ & Converted to HD & $\begin{array}{l}\text { CAM ( } 8 \text { weeks), AMK (8 } \\
\text { weeks) }\end{array}$ \\
\hline 15 & 2012 & $\begin{array}{l}12 \\
\text { months }\end{array}$ & DMN & peritonitis & $\begin{array}{l}\text { Catheter } \\
\text { removal }\end{array}$ & Converted to HD & CAM (3 months) \\
\hline 6 & 2011 & $\begin{array}{l}18 \\
\text { months }\end{array}$ & DM, IHD, HTN & $\mathrm{ESI}, \mathrm{TI}$ & $\begin{array}{l}\text { Catheter } \\
\text { removal }\end{array}$ & Converted to HD & CAM (6 weeks) \\
\hline 6 & 2011 & $\begin{array}{l}21 \\
\text { months }\end{array}$ & DM, HTN & ESI & Untreated & Paliative care & Untreated \\
\hline
\end{tabular}


Table 1 Comparison of the present case with previously reported PD-associated infections caused by Mycobacterium abscessus (Continued)

\begin{tabular}{|c|c|c|c|c|c|c|c|}
\hline Reference & Year & $\begin{array}{l}\text { Duration } \\
\text { of PD }\end{array}$ & $\begin{array}{l}\text { Cause of ESRD, } \\
\text { Underlying disease }\end{array}$ & $\begin{array}{l}\text { Infection } \\
\text { type at } \\
\text { initial treatment }\end{array}$ & $\begin{array}{l}\text { Surgical } \\
\text { intervention }\end{array}$ & Clinical outcome & Antibiotics (duration) \\
\hline 6 & 2011 & $\begin{array}{l}40 \\
\text { months }\end{array}$ & HTN & peritonitis & $\begin{array}{l}\text { Catheter } \\
\text { removal }\end{array}$ & Converted to HD & $\begin{array}{l}\text { CAM ( } 4 \text { weeks), AMK (4 } \\
\text { weeks) }\end{array}$ \\
\hline 6 & 2011 & $\begin{array}{l}6 \\
\text { months }\end{array}$ & DM & ESI, peritonitis & $\begin{array}{l}\text { Catheter } \\
\text { removal }\end{array}$ & Converted to HD & $\begin{array}{l}\text { CAM ( } 3 \text { months), CPFX ( } 3 \\
\text { months) }\end{array}$ \\
\hline 6 & 2011 & $\begin{array}{l}36 \\
\text { months }\end{array}$ & $\mathrm{DM}, I H D, H T N$ & $\begin{array}{l}\mathrm{ESI}, \mathrm{TI} \\
\text { peritonitis }\end{array}$ & $\begin{array}{l}\text { Catheter } \\
\text { removal }\end{array}$ & Converted to HD & CAM, AMK (N/A) \\
\hline 6 & 2011 & $\begin{array}{l}40 \\
\text { months }\end{array}$ & $\mathrm{DM}, I \mathrm{HD}, \mathrm{HTN}$ & $\mathrm{ESI}, \mathrm{TI}$ & $\begin{array}{l}\text { Catheter } \\
\text { removal }\end{array}$ & $\begin{array}{l}\text { Converted to HD, and reinserted } \\
\text { a new PD catheter after } 6 \text { weeks }\end{array}$ & $\begin{array}{l}\text { CAM ( } 6 \text { weeks), EB ( } 2 \\
\text { weeks) }\end{array}$ \\
\hline 6 & 2011 & $\begin{array}{l}46 \\
\text { months }\end{array}$ & DM, IHD, HTN & $\begin{array}{l}\mathrm{ESI}, \mathrm{TI} \\
\text { peritonitis }\end{array}$ & $\begin{array}{l}\text { Catheter } \\
\text { removal }\end{array}$ & $\begin{array}{l}\text { Converted to } \mathrm{HD} \text {, and reinserted } \\
\text { a new PD catheter after } 3 \\
\text { months }\end{array}$ & $\begin{array}{l}\text { CAM ( } 3 \text { months), AMK ( } 6 \\
\text { weeks) }\end{array}$ \\
\hline 16 & 2007 & $\begin{array}{l}11 \\
\text { months }\end{array}$ & CGN & $\mathrm{ESI}, \mathrm{TI}$ & $\begin{array}{l}\text { Simultaneous } \\
\text { catheter removal } \\
\text { and reinsertion }\end{array}$ & $\begin{array}{l}\text { Removed the reinserted catheter } \\
\text { because of developing } \\
\text { peritonitis, and converted to HD }\end{array}$ & $\begin{array}{l}\text { CAM (7 weeks), AMK (3 } \\
\text { weeks), CPFX (3 weeks) }\end{array}$ \\
\hline 17 & 2005 & N/A & SLE & $\mathrm{ESI}$ & $\begin{array}{l}\text { Catheter } \\
\text { removal }\end{array}$ & $\begin{array}{l}\text { Converted to HD, and reinserted } \\
\text { a new PD catheter after } 3 \\
\text { months }\end{array}$ & $\begin{array}{l}\text { CAM ( } 6 \text { weeks), AMK ( } 6 \\
\text { weeks) }\end{array}$ \\
\hline 18 & 1998 & $\begin{array}{l}12 \\
\text { months }\end{array}$ & DMN & peritonitis & $\begin{array}{l}\text { Catheter } \\
\text { removal }\end{array}$ & Converted to HD & $\begin{array}{l}\text { CAM ( } 3 \text { months), AMK ( } 3 \\
\text { months) }\end{array}$ \\
\hline
\end{tabular}

AMK amikacin, AZM azithromycin, CAM clarithromycin, CEZ cefazolin, CFX cefoxitin, CGN chronic glomerulonephritis, CPFX ciprofloxacin, DM diabetes mellitus, DMN diabetic nephropathy, $D O X Y$ doxycycline, $E B$ ethambutol, ESI exit-site infection, $F$ female, $F R P M$ faropenem, GM gentamicin, $H D$ hemodialysis, $H T N$ hypertension, IgAN immunoglobulin A nephropathy, IHD ischemic heart disease, IPM imipenem, LVFX levofloxacin, $M$ male, MEPM meropenem, MFIPC flucloxacillin, MFLX moxifloxacin, MPA microscopic polyangitis, N/A not available, PD peritonealdialysis, RFP rifampicin, SLE systemic lupus erythematosus, TGC tigecycline, TI tunnel infection, TIPC/CVA ticarcillin/clavulanic acid, VCM vancomycin,

Although the susceptibilities from the reported cases are unclear, 23 cases $(82.1 \%)$ were treated using clarithromycin and 15 cases $(53.6 \%)$ were treated using amikacin, with various durations of antibiotic therapy. The ATS/ IDSA suggests that a minimum treatment of 4 months is necessary to provide a high likelihood of cure for serious disease, and 6 months of therapy is recommended for bone infections $[20,25]$. Thus, although the precise treatment duration remains unclear, several months are likely necessary to successfully treat PD-associated infection. However, due to limited sensitivity to antibiotics and their side effects, 11 cases eventually shifted to monotherapy treatment, of which 9 were oral clarithromycin monotherapy. There was no relapse of infection in 9 cases, and 4 of them resumed PD, supporting the possibility to control infection even with monotherapy treatment. Although clarithromycin is the only effective antibiotic at present, single agent treatment is not desirable, due to the possible induction of resistant bacteria. Even in the ISPD guidelines, there is no statement on the selection of antibiotics and treatment period after sensitivity is determined. Therefore, further studies are necessary to elucidate the optimal treatment regime.

There was a delay in the identification of $M$. abscessus in this case, which we believe was due to the fact that there was a small number of bacteria present at the onset of peritonitis that led to late growth of bacteria in the media, but it is possible that the detection of gram-positive bacillus was effective for the early identification of Mycobacterium spp.. Thus, the simultaneous reinsertion of a new PD catheter might have prolonged the ESI and influenced the progression to peritonitis. Therefore, NTM should be considered as a possible causative organism in cases of refractory ESI or TI. Furthermore, catheter removal is usually necessary in cases of $M$. abscessus PD-associated infection, and reinsertion should only be attempted after complete resolution of peritoneal symptoms after several months of antibiotic therapy. $M$. abscessus is the most resistant bacterium among acid-fast bacteria, and further consideration is needed regarding the selection and treatment period of antibiotics.

\section{Abbreviations \\ ATS/IDSA: American Thoracic Society/Infectious Diseases Society of America; CAM: Clarithromycin; CRP: C-reactive protein; ESI: Exit-site infection; \\ GPR: Gram-positive rod; HD: Hemodialysis; ISPD: International Society for Peritoneal Dialysis; MRCNS: Methicillin-resistant coagulase-negative Staphylo- coccus; NTM: Non-tuberculous mycobacteria; PD: Peritoneal dialysis; RGNTM: Ruyon classification group IV of rapidly-growing mycobacteria; Tl: Tunnel infection}

\section{Acknowledgements}

Not applicable.

\section{Funding}

This study was not supported financially by any public, private or non-forprofit organization. 


\section{Availability of data and materials}

Further clinical data and images to support this case are available from the corresponding author upon reasonable request.

\section{Authors' contributions}

RY was the treating physician and wrote the bulk of the manuscript. KT, KY, $\mathrm{ME}$ and $\mathrm{TI}$ also treated the patient and critically revised the manuscript. HS performed urologic intervention and was the consultant for this case. RY, MK, SF and AY contributed to data collection, analysis and interpretation. All authors have read and approved the final manuscript.

\section{Author's information}

Not applicable.

\section{Ethics approval and consent to participate} Not applicable.

\section{Consent for publication}

Written informed consent was obtained from the patient for publication of this case report and any accompanying images.

\section{Competing interests}

The authors declare that they have no competing interests.

\section{Publisher's Note}

Springer Nature remains neutral with regard to jurisdictional claims in published maps and institutional affiliations.

\section{Author details}

'Division of Nephrology, Shimane University Hospital, 89-1, Enya-cho, Izumo, Shimane 693-8501, Japan. ${ }^{2}$ Department of Urology, Shimane University Faculty of Medicine, 89-1, Enya-cho, Izumo, Shimane 693-8501, Japan.

Received: 15 May 2018 Accepted: 22 November 2018

Published online: 29 November 2018

\section{References}

1. Piraino B, Bernardini J, Sorkin M. The influence of peritoneal catheter exit-site infections on peritonitis, tunnel infections, and catheter loss in patients on continuous ambulatory peritoneal dialysis. Am J Kidney Dis. 1986;8:436-40.

2. van Diepen AT, Tomlinson GA, Jassal SV. The association between exit site infection and subsequent peritonitis among peritoneal dialysis patients. Clin J Am Soc Nephrol. 2012;7:1266-71.

3. Szeto CC, Leung CB, Chow KM. Change in bacterial aetiology of peritoneal dialysis-related peritonitis over 10 years: experience from a Centre in SouthEast Asia. Clin Microbiol Infect. 2005;11:837-9.

4. Song Y, Wu J, Yan H, Chen J. Peritoneal dialysis-associated nontuberculous mycobacterium peritonitis: a systematic review of reported cases. Nephrol Dial Transplant. 2012;27:1639-44.

5. Li PK, Szeto CC, Piraino B, et al. ISPD peritonitis recommendations: 2016 update on prevention and treatment. Perit Dial Int. 2016;36:481-508.

6. Renaud CJ, Subramanian S, Tambyah PA, Lee EJ. The clinical course of rapidly growing nontuberculous mycobacterial peritoneal dialysis infections in Asians: a case series and literature review. Nephrology (Carlton). 2011;16:174-9.

7. Jiang SH, Roberts DM, Clayton PA, Jardine M. Non-tuberculous mycobacterial PD peritonitis in Australia. Int Urol Nephrol. 2013;45:1423-8.

8. Kusunoki S, Ezaki T, Tamesada M. Application of colorimetric microdilution plate hybridization for rapid genetic identification of 22 Mycobacterium species. J Clin Microbiol. 1991;29:1596-603.

9. Mooren VHJF, Bleeker MWP, van Ingen J, Hermans MHA, Wever PC Disseminated Mycobacterium abscessus infection in a peritoneal dialysis patient. IDCases. 2017;9:6-7.

10. Hibi A, Kasugai T, Kamiya K. Peritoneal dialysis-associated catheter infection caused by Mycobacterium abscessus in an elderly patient who was successfully treated with catheter removal. CEN Case Rep. 2017;6:175-9.

11. Yang TK, Lee JJ, Lu PL, Kuo HT, Kuo MC, Chen HC. Peritoneal Dialysisassociated peritonitis caused by Mycobacterium abscessus. Perit Dial Int. 2015;35:369-71.

12. Tsai SF. Catheter related infection due to Mycobacterium abscessus in a patient under peritoneal dialysis. Ther Apher Dial. 2013;17:349-50.
13. Lo MW, Mak SK, Wong YY, et al. Atypical mycobacterial exit-site infection and peritonitis in peritoneal dialysis patients on prophylactic exit-site gentamicin cream. Perit Dial Int. 2013;33:267-72.

14. Jo A, Ishibashi Y, Hirohama D, Takara Y, Kume H, Fujita T. Early surgical intervention may prevent peritonitis in cases with Tenckhoff catheter infection by nontuberculous mycobacterium. Perit Dial Int. 2012;32:227-9.

15. Siddiqi N, Sheikh I. Peritonitis caused by Mycobacterium abscesses in patients on continuous ambulatory peritoneal dialysis. Saudi J Kidney Dis Transpl. 2012;23:321-4.

16. Kameyama H, Mori $Y$, Kimura $T$, et al. A case report of Mycobacterium abscessus peritonitis in a peritoneal dialysis patient. Ther Apher Dial. 2007:11:449-51.

17. Ellis EN, Schutze GE, Wheeler JG. Nontuberculous mycobacterial exit-site infection and abscess in a peritoneal dialysis patient. A case report and review of the literature. Pediatr Nephrol. 2005;20:1016-8.

18. Slagle KM, Oblack DL. Mycobacterium abscessus peritonitis: a case report. Clin Lab Sci. 1998;11:206-8.

19. Pierce DA, Williamson JC, Mauck VS, Russell GB, Palavecino E, Burkart JM. The effect on peritoneal dialysis pathogens of changing topical antibiotic prophylaxis. Perit Dial Int. 2012;32:525-30.

20. Griffith DE, Aksamit T, Brown-Elliott BA, et al. An official ATS/IDSA statement: diagnosis, treatment, and prevention of nontuberculous mycobacterial diseases. Am J Respir Crit Care Med. 2007;175:367-416.

21. Stone MS, Wallace RJ Jr, Swenson JM, Thornsberry C, Christensen LA. Agar disk elution method for susceptibility testing of Mycobacterium marinum and Mycobacterium fortuitum complex to sulfonamides and antibiotics. Antimicrob Agents Chemother. 1983;24:486-93.

22. Swenson JM, Wallace RJ Jr, Silcox VA, Thornsberry C. Antimicrobial susceptibility of five subgroups of Mycobacterium fortuitum and Mycobacterium chelonae. Antimicrob Agents Chemother. 1985;28:807-11.

23. Brown BA, Wallace RJ Jr, Onyi GO, De Rosas V, Wallace RJ 3rd. Activities of four macrolides, including clarithromycin, against Mycobacterium fortuitum, Mycobacterium chelonae, and M. chelonae-like organisms. Antimicrob Agents Chemother 1992;36:180-184.

24. Wallace RJ Jr, Brown BA, Onyi GO. Susceptibilities of Mycobacterium fortuitum biovar. Fortuitum and the two subgroups of Mycobacterium chelonae to imipenem, cefmetazole, cefoxitin, and amoxicillin-clavulanic acid. Antimicrob Agents Chemother. 1991;35:773-5.

25. Wallace RJ Jr, Swenson JM, Silcox VA, Bullen MG. Treatment of nonpulmonary infections due to Mycobacterium fortuitum and Mycobacterium chelonei on the basis of in vitro susceptibilities. J Infect Dis. 1985:152:500-14.

\section{Ready to submit your research? Choose BMC and benefit from:}

- fast, convenient online submission

- thorough peer review by experienced researchers in your field

- rapid publication on acceptance

- support for research data, including large and complex data types

- gold Open Access which fosters wider collaboration and increased citations

- maximum visibility for your research: over $100 \mathrm{M}$ website views per year

At BMC, research is always in progress.

Learn more biomedcentral.com/submissions 